\title{
Konstrukcja zmodernizowanej spalinowej lokomotywy pasażerskiej serii SP32 (312D)
}

\author{
$W$ artykule zaprezentowano opis konstrukcji $i$ parametry zmodernizowanej \\ lokomotywy spalinowej pasażerskiej serii SP32 (312D), której projekt \\ modernizacji opracowany zostat w Instytucie Pojazdów Szynowych Politechniki \\ Krakowskiej, a prototyp wykonuje InterLok S.A Piła. Opisano zakres \\ modernizacji $w$ odniesieniu do układów mechanicznych, pneumatycznych $i$ \\ elektrycznych. Zaprezentowano nowe rozwiazania z zakresu ergonomii zastoso- \\ wane w kabinie maszynisty
}

\section{Wstęp}

Lokomotywy spalinowe serii SP32 o mocy 960 $\mathrm{kW}(1300 \mathrm{KM})$ zostały zakupione przez PKP w Rumunii $\mathrm{w}$ drugiej połowie lat osiemdziesiatych $\mathrm{z}$ przeznaczeniem do prowadzenia pociągów pasażerskich o masie około $250 \mathrm{Mg}$ z prędkościami do $100 \mathrm{~km} / \mathrm{h}$. Ogółem dostarczonych zostało 150 lokomotyw, z których ze względu na duże koszty eksploatacyjne, awaryjność oraz zastosowane przestarzałe, $\mathrm{z}$ technicznego punktu widzenia, rozwiązania w ruchu pasażerskim wykorzystywanych było z każdym rokiem coraz mniej tych lokomotyw. Czesść lokomotyw SP32 z ww. parku została spisana $\mathrm{z}$ inwentarza i pocięta na złom, a obecnie w eksploatacji znajduje się około 20 sztuk.

$\mathrm{Na}$ początku lat 90 . podjęto pierwszą modernizację (remotoryzację) tych lokomotyw polegającą na zastąpieniu silnika spalinowego typu M820SR silnikiem typu 12V396TC12 firmy Faur oraz wdrożeniu mikroprocesorowego regulatora obrotów i mocy firmy Woodward. Zmiany te wprowadzone tylko na sześciu lokomotywach poprawiły nieznacznie właściwości trakcyjne i niezawodność lokomotywy.

Na przełomie lat 1999/2000 w oparciu o rozwiązania IPS Tabor [1] przystapiono do kolejnej modernizacji tych lokomotyw, w trakcie której zabudowano silnik spalinowy typu 12V396TC14 firmy MTU wraz z nowym układem sprzęgieł agregatu prądotwórczego, wykonano nowy układ sterowania zespołami i cała lokomotywa $\mathrm{z}$ centralnym sterownikiem mikroprocesorowym lokomotywy. Modernizacji poddano układ hamulca elektropneumatycznego i elektrodynamicznego oraz wyposażenie kabiny maszynisty. Zmiany te wprowadzono na 10 szt. tych lokomotyw. W wyniku przeprowadzonej modernizacji uzyskano poprawę wskaźników eksploatacyjnych, w tym niezawodności lokomotywy $\mathrm{w}$ porównaniu $\mathrm{z}$ lokomotywami przed modernizacją.

W 2008 r. w IPSz Politechniki Krakowskiej przeprowadzono analizę techniczno-ekonomiczną zmian zakresu modernizacji lokomotyw SP32 uwzględniającego, między innymi, nowe wymagania techniczne stawiane przez przewoźników. W trakcie tej analizy dokonano również oceny wdrożonych w poprzedniej modernizacji rozwiązań technicznych w oparciu o dane otrzymane od użytkowników tych lokomotyw. Pozwoliło to na opracowanie i zaproponowanie właścicielowi tych lokomotyw nowego zakresu ich modernizacji, który przedstawiono poniżej. Lokomotywa SP32 po modernizacji otrzymała oznaczenie 312D.

\section{Dane ogólne i parametry lokomotywy SP32 po modernizacji}

Ogólny widok lokomotywy SP32 przedstawiono na rys. 1, a jej główne parametry techniczne zestawiono w tabeli 1 . Na rys. 2 przedstawiono rozmieszczenie głównych zespołów na zmodernizowanej lokomotywie SP32, a na rys. 3 charakterystyki trakcyjne przed i po modernizacji.

Ogólny widok bryły lokomotywy w wyniku przeprowadzonej modernizacji nie uległ zasadniczej zmianie. Największe zmiany wprowadzono do konstrukcji kabiny maszynisty. W związku z zabudową nowego silnika spalinowego zmianie uległa konstrukcja thumika wylotu spalin, a z dwóch wentylatorów układu chłodzenia silnika pozostał po modernizacji jeden. Zmianom konstrukcyjnym poddano również wybrane drzwi przedziałów maszynowych. Na dachu kabiny maszynisty zabudowano kompaktowy klimatyzator. Bardziej szczegółowy opis wdrożonych zmian na lokomotywie zaprezentowano w dalszej części artykutu.

W trakcie modernizacji nie wystapiła konieczność dobalastowania lokomotywy. Wózki lokomotywy wraz z silnikami trakcyjnymi oraz pozostałe elektryczne maszyny trakcyjne modernizacji nie podlegały. Zespoły te poddane zostały naprawie głównej 


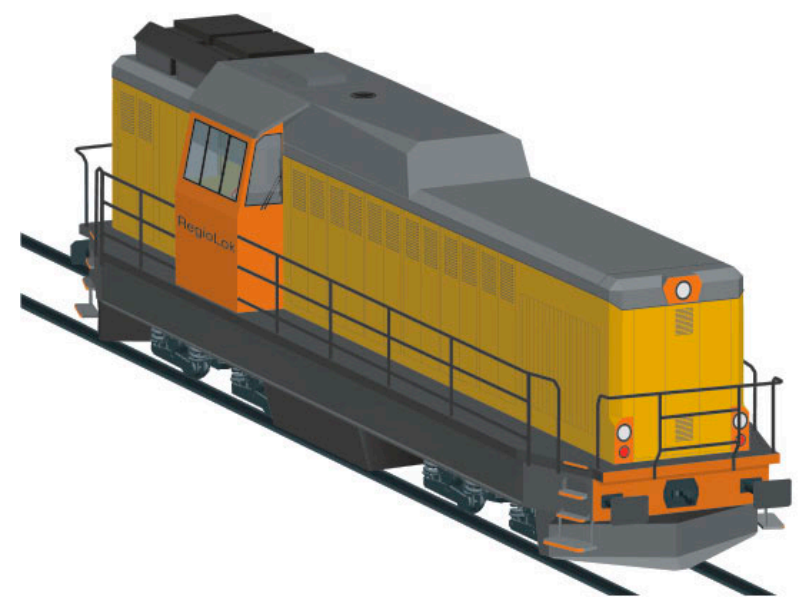

Rys. 1. Widok lokomotywy SP32 po modernizacji

zgodnie z obowiązującym zakresem i WT tej naprawy.

\section{Opis zmodernizowanych zespołów i układów lokomotywy}

\subsection{Zespół prądotwórczy}

Agregat prądotwórczy na lokomotywie SP32 składa się $\mathrm{z}$ wysokoobrotowego silnika spalinowego serii 3512B, zespołu prądnicy głównej GST-1-2, sprzęła głównego, prądnicy grzewczej GSTI, elastycznego wału sprzęgłowego oraz układów sterujących silnika.

Przy wyborze typu (producenta) silnika spalinowego do modernizowanej lokomotywy SP32 brano pod uwagę następujące czynniki:

- przedział mocy nominalnej/przy obrotach - 1100 $\mathrm{kW} / 1500 \mathrm{obr} / \mathrm{min}$;

- wymiary gabarytowe i masę, pozwalające na zabudowę silnika na ostoi w istniejącym przedziale maszynowym lokomotywy;

- zastosowanie nowoczesnych rozwiązań w konstrukcji zespołów/podzespołów silnika spalinowego;

- spełnienie wymagań Dyrektywy Komisji Europejskiej 2004/26/EC dot. wartości granicznych emisji zanieczyszczeń w spalinach;
Podstawowe parametry techniczne lokomotywy SP32 po modernizacji

Tabela 1

\begin{tabular}{|c|c|}
\hline Szerokość toru & $1435 \mathrm{~mm}$ \\
\hline Układ osi & Bo - Bo \\
\hline Skrajnia lokomotywy & wg UIC 505-1 \\
\hline Moc silnika spalinowego & $1082 \mathrm{~kW}(1470 \mathrm{KM})$ \\
\hline Moc na cele trakcyjne & $? 890 \mathrm{~kW}$ \\
\hline Moc na cele grzewcze & $? 250 \mathrm{~kW}$ \\
\hline $\begin{array}{l}\text { Znamionowe napięcie zasila- } \\
\text { nia ogrzewania wagonów }\end{array}$ & $3 \mathrm{kV} \mathrm{DC}$ \\
\hline Rodzaj przekładni & $\mathrm{AC}-\mathrm{DC}$ \\
\hline $\begin{array}{l}\text { Napięcie zasilania układów: } \\
\text { - urządzeń pomocniczych } \\
\text { - sterujących }\end{array}$ & $\begin{array}{l}3 \times 400 \mathrm{~V} \text { AC } \\
24 \mathrm{~V} \mathrm{DC}\end{array}$ \\
\hline $\begin{array}{l}\text { Nominalny nacisk zestawu na } \\
\text { tor }\end{array}$ & $183 \mathrm{kN}$ \\
\hline Siła pociągowa przy rozruchu & $>210 \mathrm{kN}$ \\
\hline Masa lokomotywy & $74,5 \mathrm{Mg}$ \\
\hline $\begin{array}{l}\text { Prędkość: } \\
\text { - maksymalna } \\
\text { - ciągła }\end{array}$ & $\begin{array}{l}100 \mathrm{~km} / \mathrm{h} \\
23 \mathrm{~km} / \mathrm{h}\end{array}$ \\
\hline Najmniejszy promień łuku & $160 \mathrm{~m}$ \\
\hline System hamulca & $\begin{array}{l}\text { SAB - Wabco/tablica } \\
\text { pneumatyczna }\end{array}$ \\
\hline Elektrodynamiczny & oporowy \\
\hline Postojowy & sprężynowy \\
\hline Sterowanie lokomotywą & $\begin{array}{l}\text { trakcja wielokrotna/2 } \\
\text { lokomotywy }\end{array}$ \\
\hline
\end{tabular}

- cenę i warunki zakupu wraz z kosztami utrzymania w eksploatacji, resurs naprawczy,

- doświadczenie producenta w zakresie stosowania silników na lokomotywach spalinowych;

- obecność na polskim rynku sieci obsługi serwisowej oraz dostępu do części zamiennych.

W wyniku przeprowadzonej przedmiotowej analizy wśród znanych na rynku producentów silników spalinowych, wybrano do zastosowania na modernizowanej lokomotywie SP32 silnik spalinowy Caterpillar serii 3512B. Podstawowe dane techniczne silnika przedstawiono w tabeli 2.

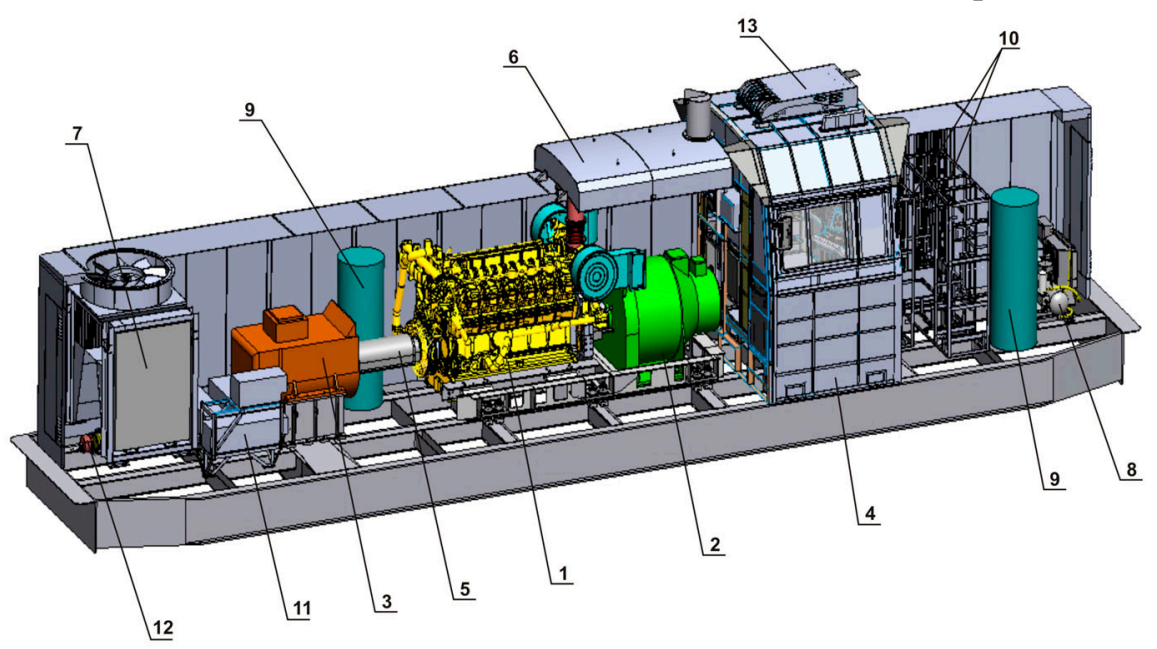

Rys. 2. Rozmieszczenie głównych zespołów na zmodernizowanej lokomotywie SP32: $1-$ silnik spalinowy CAT 3512B, 2 - prądnica główna GST-1-2, 3 - prądnica grzewcza GSTI, $4-$ kabina maszynisty, 5 - wał elastyczny sprzęgłowy, 6 - thumik wylotu spalin, 7 - agregat chłodniczy, 8 - sprężarka powietrza, 9 - wentylatory silników trakcyjnych, 10 - szafy elektryczne NN, WN, 11 - zespół przetwornicfalowników, 12 - podgrzewacz Webasto, 13 - klimatyzator 
Tabela 2

\begin{tabular}{|l|c|c|}
\hline \multicolumn{1}{|c|}{$\begin{array}{l}\text { Nazwa parametru silnika } \\
3512\end{array}$} & Jednostka & Wartość \\
\hline Moc nominalna & $\mathrm{kW} \mathrm{(KM)}$ & $1082(1470)$ \\
\hline $\begin{array}{l}\text { Obroty nominalne/biegu } \\
\text { jałowego }\end{array}$ & $\mathrm{obr} / \mathrm{min}$ & $1500 / 600$ \\
\hline $\begin{array}{l}\text { Średnica cylindra/skok } \\
\text { tłoka }\end{array}$ & $\mathrm{mm}$ & $170 / 190$ \\
\hline $\begin{array}{l}\text { Pojemność skokowa } \\
\text { silnika }\end{array}$ & $\mathrm{dm}^{3}$ & 51,8 \\
\hline $\begin{array}{l}\text { Pojemność układu } \\
\text { chłodzenia }\end{array}$ & $\mathrm{dm}^{3}$ & 157 \\
\hline $\begin{array}{l}\text { Pojemność układu } \\
\text { olejowego }\end{array}$ & $\mathrm{dm}{ }^{3}$ & 310 \\
\hline $\begin{array}{l}\text { Zużycie paliwa: } \\
- \text { bieg jałowy } \\
- \text { jednostkowe przy mocy } \\
\text { nominalnej }\end{array}$ & $\mathrm{g} / \mathrm{kW} \cdot \mathrm{h}$ \\
\hline Zużycie oleju silnikowego & $\mathrm{g} / \mathrm{kW} \cdot \mathrm{h}$ & 10,0 \\
\hline Wtrysk paliwa & - & pompowtryskiwacze \\
\hline Masa suchego silnika & $\mathrm{kg}$ & 6200 \\
\hline Wymiary: L/B/H & $\mathrm{mm}$ & $2675 \times 1560 \times 1720$ \\
\hline
\end{tabular}

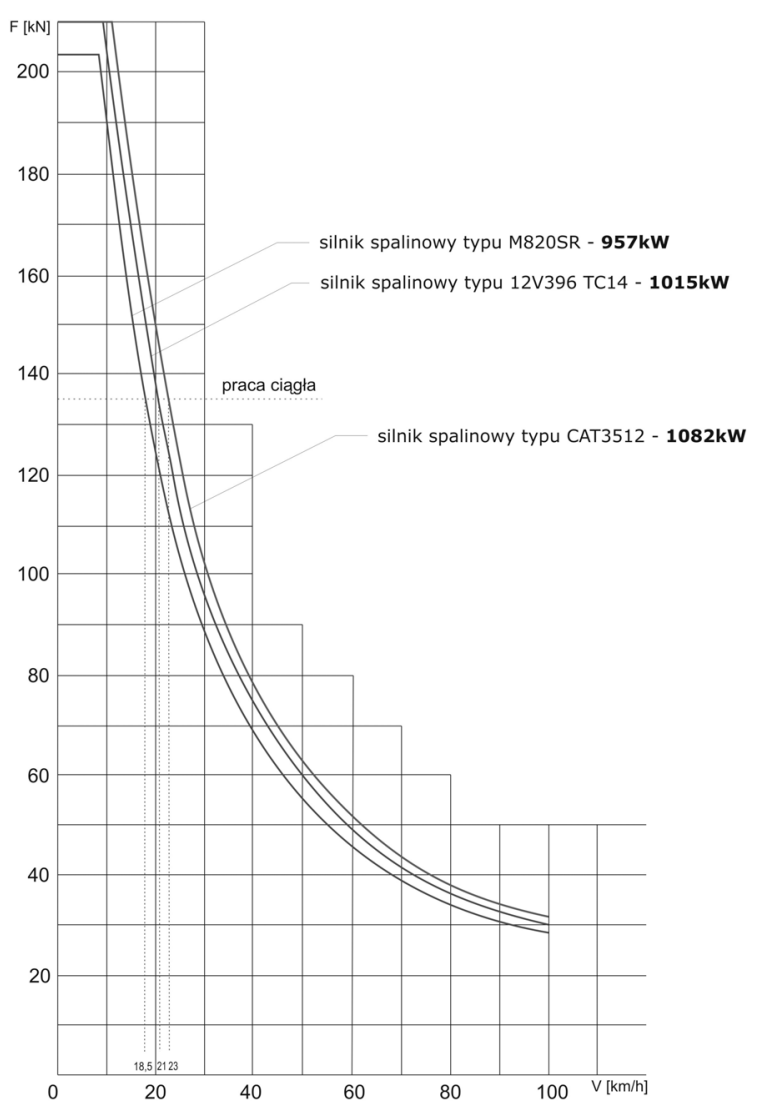

Rys. 3. Charakterystyki trakcyjne lokomotywy SP32 przed i po modernizacji

Silnik spalinowy wraz z zespołem prądnicy głównej posadowiony jest na zmodernizowanej dotychczasowej ramie podsilnikowej. Silnik napędza poprzez sprzęgło elastyczne firmy Centa dotychczasowy zespół prądnic synchronicznych GST-1-2. Z drugiej strony silnika za pośrednictwem elastycznego wału sprzęgłowego napędzana jest dotychczasowa prądnica grzewcza GSTI.

Silnik 3512B dostarczany jest $\mathrm{z}$ własnym rozrusznikiem (2 szt.) oraz alternatorem na napięcie $24 \mathrm{~V} \mathrm{DC}$. Na silniku zabudowana jest własna pompa paliwowa o wydajności zapewniającej pobór paliwa bezpośrednio ze zbiornika pod ostoją. Wyeliminowana jest więc konieczność stosowania dodatkowej pompy paliwowej. Silnik spalinowy 3512B wyposażony jest w elektroniczny regulator obrotów i mocy ECM, który na lokomotywie współpracuje (komunikuje się) ze sterownikiem mikroprocesorowym układu sterowania lokomotywą.

\subsection{Układy pomocnicze silnika spalinowego}

W układzie zasilania silnika powietrzem zastosowano dwa boczne filtry powietrza zabudowane na silniku. Powietrze do zasilania silnika jest pobierane $\mathrm{z}$ otoczenia poprzez żaluzje wlotowe $\mathrm{w}$ drzwiach bocznych przedziałów maszynowych. Silnik wyposażony jest we własną chłodnicę powietrza doładowania typu „woda-powietrze".

Tłumik wylotu spalin o zmienionej konstrukcji zabudowano na dachu lokomotywy w dotychczasowym jego miejscu. Kolektor wydechowy wykonany jest w postaci odcinka pionowego kompensatora łączącego wylot spalin $\mathrm{z}$ turbosprężarek $\mathrm{z}$ wlotem tłumika spalin.

W układzie wentylacji skrzyni korbowej zabudowano specjalny filtr-separator do filtracji mieszaniny olejowo-gazowej (odmy).

Układ chłodzenia silnika spalinowego wykonany jest jako jednoobiegowy. Zabudowany na silniku termostat automatycznie steruje przepływem płynu chłodzącego pomiędzy obiegiem wewnętrznym silnika i zewnętrznym układem chłodnic. Dotychczasowy agregat chłodniczy został gruntownie zmodernizowany wraz ze zmianą sposobu napędu wentylatora. Dotychczasowe dwa wentylatory wraz $\mathrm{z}$ napędami zdemontowano, blok wentylatora $\varnothing 1100 \mathrm{~mm}$ został odcięty. W miejsce wentylatora $\varnothing 1200 \mathrm{~mm}$ zabudowano nowy moduł - wentylator wraz $\mathrm{z}$ napędem od silnika asynchronicznego. Zastosowano dwie nowe chłodnice aluminiowe typu panelowego. Wentylator posiada 4 stopnie obrotów w zależności od temperatury płynu chłodzącego. Załączeniem/wyłączeniem wentylatora steruje sterownik INTELO. Zmodyfikowano również zbiornik wyrównawczy z zastosowaniem zaworu odcinającego firmy BEHR. W układzie wstępnego podgrzewania płynu chłodzącego i oleju silnika przed jego rozruchem zastosowano podgrzewacz Webasto.

\subsection{Układ sterowania zespołami i całą lokomotywą}

W trakcie modernizacji lokomotywy SP32 ujednolicono napięcia: 
- w obwodach sterowania, sygnalizacji i kontroli do wielkości $24 \mathrm{~V}$ DC.

- w obwodach napędów urządzeń pomocniczych do wielkości $3 \times 400 \mathrm{VAC}$.

Układ sterowania realizowany jest na zmodernizowanej lokomotywie za pośrednictwem sterownika mikroprocesorowego INTELO. Schemat blokowy układu sterowania lokomotywą przedstawiono na rys. 4. Funkcje realizowane przez sterownik, algorytmy sterowania i graniczne wartości parametrów pracy mogą być modyfikowane przez zmiany w oprogramowaniu sterownika. Sterownik realizuje następujące główne funkcje:

- współpracuje z elektronicznym regulatorem ECM silnika spalinowego 3512B,

- reguluje wzbudzenie prądnicy głównej - steruje układem rozrządu lokomotywy,

- współpracuje z tablicą pneumatyczną,

- steruje pracą sprężarki, wentylatora układu chłodzenia silnika spalinowego,

- zapewnia współpracę hamulca elektrodynamicznego z hamulcem zespolonym,

- steruje układem bocznikowania silników trakcyjnych,

- automatycznie kontroluje i steruje likwidacją poślizgu kół,

- współpracuje z regulatorem napięcia prądnicy grzewczej,

- zabezpiecza układy lokomotywy, w tym silnika spalinowego.

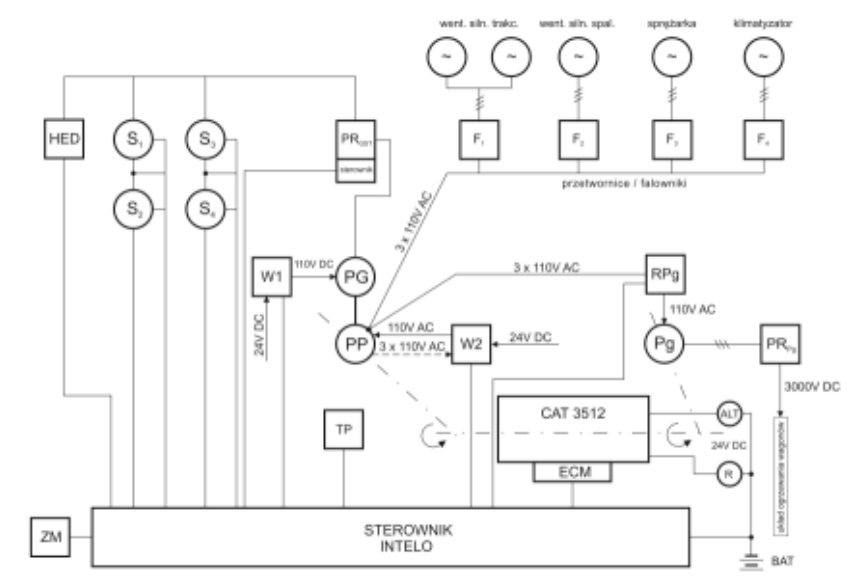

Rys. 4. Schemat blokowy układu sterowania silnikiem spalinowym i napędem zmodernizowanej lokomotywy SP32: S1, S2, S3, S4 - silniki trakcyjne; CAT 3512 - silnik spalinowy z regulatorem ECM; PRGST - prostownik gł. sterowany; F1-F4 - Przetwornice/falowniki; HED - hamulec elektrodynamiczny; Pg - prądnica grzewcza; PG - prądnica główna; RPg - regulator Pg; W1 - przekształtnik/wzbudnica PG; PRPg - prostownik Pg; PP - prądnica pomocnicza; INTELO - sterownik lokomotywy; W2 - regulator wzbudzenia PP; BAT - bateria akumulatorów $24 \mathrm{~V}$; TP - tablica pneumatyczna; ZM - pulpitowy zadajnik mocy; ALT/R - alternator/rozrusznik silnika 3512B
Lokomotywa wyposażona została $\mathrm{w}$ diagnostykę pokładową, którą objęte są sterownik (autodiagnostyka), silnik spalinowy z regulatorem oraz obwód główny lokomotywy, w tym obwód ogrzewania wagonów. Do diagnostyki wykorzystywane są przetworniki pomiarowe i sygnały, które służą procesom sterowania, regulacji i zabezpieczania. Sygnały informujące o powstałych usterkach i uszkodzeniach w układach diagnozowanych przez regulator silnika spalinowego są gromadzone w jego pamięci oraz wybrane kierowane do sterownika INTELO i prezentowane na wyświetlaczach pulpitowych.

\subsection{Obwód główny, ogrzewania i pomocniczy}

W trakcie modernizacji dokonano rekonstrukcji szaf elektrycznych WN, NN i ogrzewania. W związku $\mathrm{z}$ ujednoliceniem napięcia pokładowego do $24 \mathrm{~V}$ DC następujące aparaty: nawrotnik, styczniki liniowe, rozruchowe, pomocnicze i ogrzewania zostały dostosowane do tej wielkości napięcia. Dotychczasowe styczniki rumuńskie zawierające azbest $\mathrm{w}$ komorach gaszeniowych zostały zastąpione stycznikami typu SPG i SPO.

W obwodzie głównym dotychczasowy prostownik zastąpiono nowym prostownikiem sterowanym. Umożliwi to szybkie przejście z pozycji jazdy do hamowania elektrodynamicznego eliminując występowanie zjawisk uderzeń prądowych wywołanych magnetyzmem szczątkowym prądnicy głównej. Pozwoli to na efektywne wykorzystanie zalet hamowania elektrodynamicznego na lokomotywie.

Regulacją wzbudzenia prądnicy głównej steruje sterownik INTELO poprzez przekształtnik/wzbudnicę $24 \mathrm{~V} \mathrm{DC} / 110 \mathrm{~V}$ DC.

Największe zmiany zostały poczynione w obwodach pomocniczych lokomotywy. W wyniku modernizacji wentylatorów silników trakcyjnych, zabudowy sprężarki śrubowej SK18, wentylatora układu chłodzenia silnika spalinowego oraz klimatyzatora, zastosowano do ich napędu elektryczne silniki asynchroniczne. W związku z tym zainstalowano w obwodzie pomocniczym przetwornice/falowniki firmy ENIKA do zasilania silników asynchronicznych ww. urządzeń pomocniczych. Są to urządzenia o konstrukcji modułowej. Zasilanie przetwornic/falowników odbywa się bezpośrednio $\mathrm{z}$ zacisków prądnicy pomocniczej napięciem $3 \times 110$ V AC. Do regulacji wzbudzenia prądnicy pomocniczej zastosowano nowej konstrukcji regulator wzbudzenia inicjowany do pracy napięciem 24 V DC.

W układzie ogrzewania zastosowano nowy regulator prądnicy grzewczej spełniający następujące główne zadania:

- nastawia wartość napięcia wyjściowego prądnicy grzewczej, zadanego poprzez sterownik INTELO,

- wyłącza i załącza prądnicę grzewczą sygnałem sterownika INTELO, 
- zabezpiecza przed nadmiernym wzrostem i spadkiem napięcia wyjściowego.

Regulator prądnicy grzewczej zasilany jest bezpośrednio z zacisków prądnicy pomocniczej napięciem $3 \times 110 \mathrm{VAC}$.

Tablicę sterowniczą NN zabudowano w ścianie czołowej kabiny maszynisty, obok pulpitu od strony szafy elektrycznej $\mathrm{NN} \mathrm{z}$ dostępem maszynisty do przełączników, wskaźników i aparatów elektrycznych $\mathrm{z}$ wnętrza kabiny.

\subsection{Układ hamulca pneumatycznego}

W zmodernizowanej lokomotywie SP32 zastosowane zostały następujące rodzaje hamulców:

- zespolony hamulec elektropneumatyczny przeznaczony do hamowania zarówno lokomotywy jak i prowadzonego pociagu,

- hamulec elektrodynamiczny,

- dodatkowy hamulec do hamowania lokomotywy,

- hamulec postojowy sprężynowy,

- hamulec bezpieczeństwa.

Urządzenia wykonawcze hamulca zabudowane na wózkach pozostały bez zmian. Sterowanie działaniem układu hamulca odbywa się za pośrednictwem binarnych sygnałów elektrycznych przekazywanych przez manipulatory hamulca zespolonego i dodatkowego zabudowanych na pulpitach sterowniczych. Wszystkie aparaty pneumatyczne i elektropneumatyczne zostały zabudowane na tablicy pneumatycznej produkcji IPS Tabor. Na tablicy pneumatycznej zabudowano następujące układy:

- sterowania hamulcem zespolonym pociagu i lokomotywy,

- sterowania hamulcem dodatkowym lokomotywy,

- czuwaka, SHP i radiostopu,

- współpracy hamulca elektrodynamicznego z hamulcem pneumatycznym,

- pneumatyczny piasecznic,

- pneumatyczny rozrządu lokomotywy.

Do zasilania układu pneumatycznego na zmodernizowanej lokomotywie wykorzystano agregat sprężarkowy ze sprężarką śrubową SK18. Silnik asynchroniczny sprężarki zasilany jest z prądnicy pomocniczej poprzez przetwornicę/falownik napięciem $3 \times 400 \mathrm{~V}$ DC. Agregat sprężarkowy zabudowany został na lokomotywie w miejscu dotychczasowej sprężarki.

\section{6. Układ zabezpieczenia przeciwpożarowego.}

W lokomotywie zostały zabudowane dwa obwody sygnalizacji przeciwpożarowej składające się z czujników wykrywania ognia (temperatury) współpracujących z centralką sygnalizacji pożarowej. Czujniki temperatury zlokalizowane są $\mathrm{w}$ kabinie maszynisty i szafie WN (jeden obwód) oraz w przedziale silnika spalinowego. Wykrycie ognia sygnalizowane jest na pulpicie maszynisty - lampka sygnalizacyjna oraz sygnalizatorem dźwiękowym. W przypadku wykrycia ognia przez czujniki i informacji centralki, maszynista specjalnym przyciskiem uruchamia system gaszenia. $\mathrm{Z}$ chwila uruchomienia systemu gaszeniowego $\mathrm{Z}$ przycisku zostaje zatrzymany silnik spalinowy. Na lokomotywie SP32 został zainstalowany system gaśniczy składający się z układu rurek i dysz oraz butli gaśniczej wypełnionej środkiem gaśniczym. Ponadto lokomotywa wyposażona jest $\mathrm{w}$ gaśnice proszkowe umieszczone $\mathrm{w}$ kabinie maszynisty, natomiast wszystkie materiały użyte $w$ budowie lokomotywy i jej urządzeń, zespołów oraz instalacja elektryczna spełniają wymagania w zakresie palności, dymienia i toksyczności gazów.

\subsection{Modernizacja kabiny maszynisty}

Podczas prac projektowych związanych z modernizacją kabiny maszynisty lokomotywy SP32 przeanalizowano i zinwentaryzowano dotychczasowe rozwiązania fabryczne producenta lokomotyw oraz rozwiązania zastosowane podczas modernizacji w latach 19992003 [1]. W wyniku przeprowadzonych analiz, oraz uzgodnień z zamawiającym opracowano zakres rozwiązań i wyposażenia kabiny maszynisty.

W zmodernizowanej kabinie zastosowano nowoczesne rozwiązania techniczne oraz wysoki poziom wzornictwa - designu, co w efekcie przyczynia się do zapewnienia wysokiego komfortu pracy maszynistów.

Głównymi zmianami dotyczącymi konstrukcji kabiny maszynisty było podniesienie skosów jej dachu w celu zwiększenia przestrzeni użytkowej oraz zabudowa wszystkich okien i szyb w technologii klejenia w celu poprawienia szczelności oraz estetyki. Dzięki podniesieniu dachu maszynista zyskał więcej przestrzeni nad głową w pozycji stojącej. Umożliwiło to również estetyczne zamocowanie lamp w suficie bezpośrednio nad pulpitami, a $\mathrm{w}$ związku $\mathrm{z}$ zastosowaniem bogatego wyposażenia socjalnego dało możliwość zabudowy dodatkowych elementów.
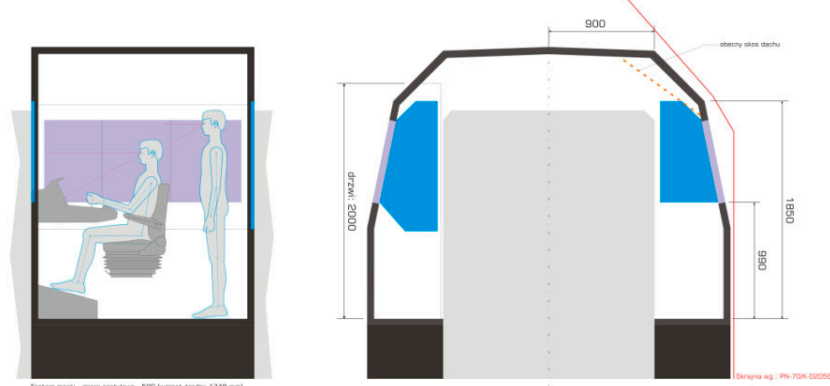

Rys. 5. Podstawowe założenia przebudowy dachu kabiny i stanowisk maszynisty

Zostały wykonane również całkowicie nowe drzwi do kabiny z powiększoną szybą, zapewniająca lepszą widoczność oraz kształcie nawiązującym odpowiednio do bryły lokomotywy.

$\mathrm{Na}$ dachu kabiny zainstalowany został kompaktowy klimatyzator. Jego lokalizacja w osi wzdłużnej kabiny powoduje, że zimne powietrze nie jest kierowane bezpośrednio na głowę siedzącego maszynisty 


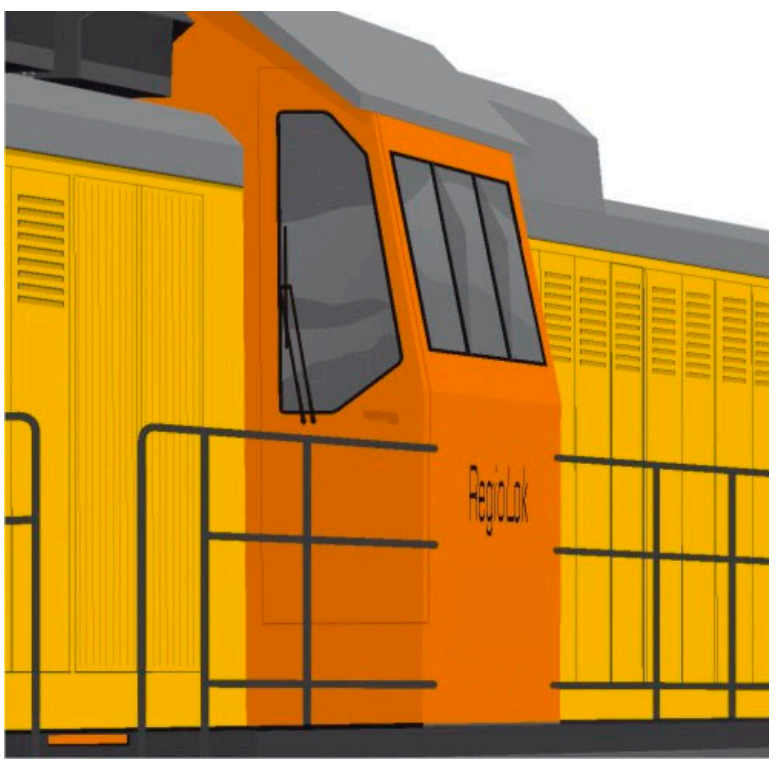

Rys. 6. Nowe drzwi kabiny maszynisty

lecz w przestrzeń „,wolną” co ma bardzo duże znaczenie dla komfortu jego pracy i zdrowia.

Wewnątrz kabiny zastosowano dwa ergonomiczne pulpity sterownicze zlokalizowane po przekątnej kabiny. Innowacyjnym rozwiązaniem jest zastosowanie pulpitów budowy „kominowej”. Polega ono na zabudowie modułów pulpitu na wysokość od podłogi do sufitu. Oprócz strony estetycznej ma to znaczenie związane $\mathrm{z}$ usprawnieniem montażu wyposażenia kabiny oraz $\mathrm{z}$ ułatwieniem jego utrzymania i serwisu.

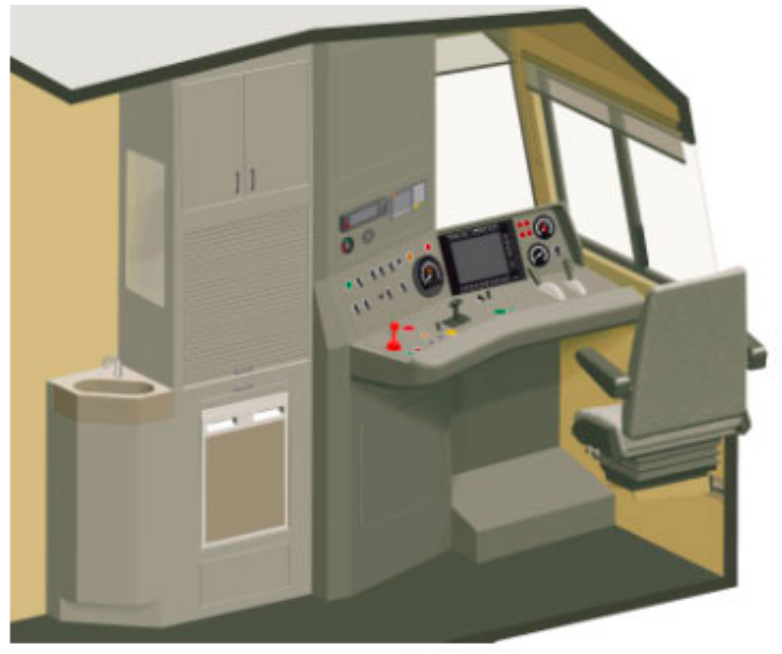

Rys. 7. Wizualizacja stanowiska maszynisty

Zabudowa „kominowa” powoduje między innymi, że wszystkie podzespoły dotychczas zawieszane na ścianach zakryte zostały wyłożeniami pulpitów, a dostęp do poszczególnych podzespołów zapewniaja klapy inspekcyjne. Wszystkie wiązki kablowe biegnace spod podłogi do pulpitów oraz do urządzeń w suficie poprowadzone są wewnątrz konstrukcji pulpitów. Dzięki temu nie ma konieczności „wciaggania” instalacji przed założeniem wyłożeń wnętrza kabiny, gdyż większość wiązek można montować już po zabudowaniu konstrukcji pulpitów przez wspomniane wcześniej klapy inspekcyjne.
W kabinie zabudowano nowoczesne fotele maszynisty. Konstrukcja każdego z nich umożliwia składanie oparcia do poziomu siedziska, co dzięki zamontowaniu foteli na prowadnicach do ścian bocznych kabiny, pozwala na ich wsuwanie pod blaty pulpitów. Rozwiązanie to znacząco poprawia funkcjonalność kabiny - zwiększona zostaje ilość przestrzeni wolnej, gdy jeden $z$ foteli jest nieużywany. Natomiast przy prowadzeniu jazdy z pozycji stojącej maszynista nie ma ograniczonych ruchów, gdyż fotel może być odsunięty daleko od blatu pulpitu lub schowany pod niego. Dodatkowo fotele posiadają szereg regulacji wymaganych przez normy, takie jak regulacje: wysokości, kąta pochylenia oparcia, kąta pochylenia siedziska, wysuwu. Istnieje także możliwość regulacji odsuwu fotela od ściany bocznej kabiny oraz wysuwu siedziska $\mathrm{w}$ stosunku do oparcia. Taka liczba regulacji $\mathrm{w}$ fotelu oraz regulowany na wysokość podnóżek wpływa bezpośrednio na podniesienie komfortu pracy maszynisty.

W każdym pulpicie zastosowana jest nagrzewnica powietrza sterowana elektrycznie $\mathrm{z}$ rozprowadzeniem powietrza na wnętrze kabiny oraz $\mathrm{z}$ nadmuchem na nogi. Nagrzewnice posiadają indywidualne sterowanie z pulpitów.

Na każdym z pulpitów poza ergonomicznie rozmieszczonymi manipulatorami, których liczba została ograniczona do koniecznego minimum, zastosowano terminal diagnostyki pokładowej z 10,4 calowym ekranem, terminal urządzenia radiołączności z mikrofonem wyprowadzonym $\mathrm{w}$ rejon optymalnego zasięgu rąk oraz terminal satelitarnego rozkładu jazdy. Zawór hamulca bezpieczeństwa zlokalizowany został na blacie pulpitu.
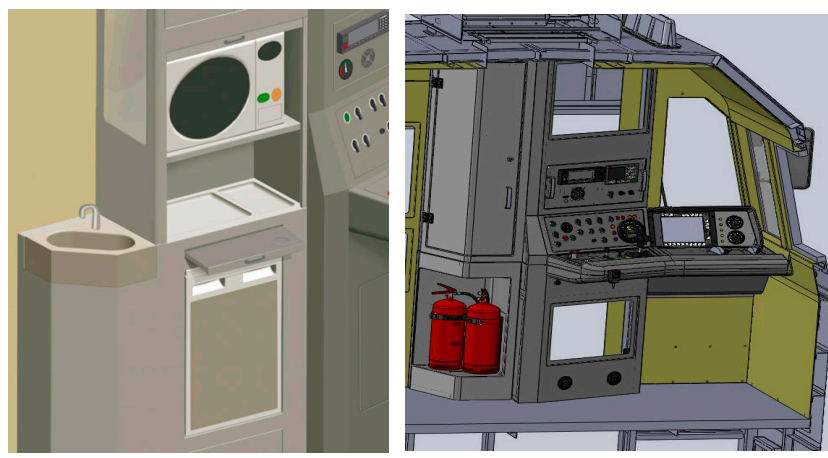

Rys. 8. Wyposażenie socjalne

Jak było wspomniane w kabinie zastosowano bogate wyposażenie socjalne. Przy jednym pulpicie część socjalna w zabudowie modułowej zawiera narożną umywalkę, kuchenkę mikrofalową, lodówkę, wysuwany blat, schowek, szafkę ogólnego zastosowania oraz lustro. Przy drugim pulpicie znajduje się natomiast zamykana szafka ubraniowa, schowek na gaśnice oraz śmietniczka.

Kolor pulpitów w odcieniu ciepłej szarości jest właściwy dla komfortowego prowadzenia pojazdu eliminuje powstawanie odblasków w wyniku czego 
nie męczy wzroku na skutek olśnień oraz zapewnia prawidłowy odczyt wskazań urządzeń sygnalizacyjnych. Elementy zabudowy wyposażenia socjalnego posiadają jaśniejszy odcień szarości w celu zapewnienia wizualnego odróżnienia funkcji socjalnej od sterowniczej oraz rozjaśnienia wnętrza kabiny poza polem patrzenia maszynisty. Wyłożenie ścian i sufitu ma kolor jasnożółty - kość słoniowa. Dodatkowo wszystkie powierzchnie wyłożeń z żywic poliestrowych (pulpity, panele, ściany) w całości posiadają matowe wykończenie.

Całe wnętrze zabudowane jest z elementów kompozytowych - laminatów poliestrowo-szklanych w wyniku czego wyeliminowane zostało odczucie tzw. ,zimnej blachy”, tak często dokuczającej maszynistom w innych pojazdach.

Oświetlenie kabiny zapewniają dwie oprawy oświetleniowe w technologii LED.

Zastosowane rozwiązania $\mathrm{w}$ kabinie maszynisty zostały sprawdzone w dotychczasowych lokomotywach zaprojektowanych przez IPSz PK i pozytywnie zaopiniowane przez użytkowników [2].

Projekt pulpitów i części socjalnej budowy modułowej z rozwiązaniem ,kominowym” został zastrzeżony przez Instytut Pojazdów Szynowych Politechniki Krakowskiej w Urzędzie Patentowym RP i podlega ochronie prawnej.

\section{Zakończenie}

Zaprezentowana konstrukcja zmodernizowanej lokomotywy SP32 oraz jej nowe zespoły i układy to pojazd trakcyjny, który będzie mógł być z powodzeniem eksploatowany przez następne 20 lat. W trakcie modernizacji zabudowane zostaną na lokomotywie podzespoły i części sprawdzone już w prawie trzyletnim okresie eksploatacji na zmodernizowanych lokomotywach serii $6 \mathrm{Dg}$ [2]. Są to w większości wyroby przemysłu krajowego lub dostarczane przez polskie firmy. Do niezbędnego minimum wykorzystano na modernizowanej lokomotywie oryginalne zespoły i części produkcji rumuńskiej.
Ocenę efektywności modernizacji lokomotywy spalinowej SP32 (312D) przeprowadzono w oparciu o analizę LCC (Life Cycle Costs) porównującą efekty ekonomiczne uzyskiwane przy eksploatacji lokomotywy SP32 przed i po modernizacji. W wyniku analizy otrzymano następujące główne wskaźniki:

- zmniejszenie zużycia paliwa w granicach 12-20\% w zależności od przyjętych warunków eksploatacji lokomotywy,

- zmniejszenie o ok. 20\% bieżących kosztów utrzymania - wdrożenie nowego cyklu planowych przeglądów i napraw,

- zmniejszenie kosztów LCC w przyjętym okresie 25 lat eksploatacji o ok. $23 \%$,

- obniżka kosztów bieżącego utrzymania o ok. 80\% wynikająca ze zmniejszenia awarii/ usterek - nieplanowych napraw - w podzespołach/układach lokomotywy,

- współczynnik gotowości technicznej na poziomie ok. 0,98 ,

- okres zwrotu nakładów poniesionych na modernizację wynosi ok. 6 lat.

Obecnie prototyp modernizowanej lokomotywy SP32 (312D) wykonywany jest w InterLok S.A. Piła.

\section{Li t e r a t u r a}

[1] Marciniak Z., Zmodernizowana spalinowa lokomotywa do ruchu pasażerskiego serii SP32 - konstrukcja i badania, Pojazdy Szynowe, 2/2001.

[2] Babet M., Tutecki A., Konstrukcja zmodernizowanej spalinowej lokomotywy manewrowej serii $6 D g$, XVIII Konferencja Naukowa Pojazdy Szynowe, Politechnika Ślaska, wrzesień 2008. 